\title{
PELAKSANAAN PENDAFTARAN TANAH OLEH PEMEGANG HAKNYA DI DESA NANGA KALIS KECAMATAN KALIS KABUPATEN KAPUAS HULU
}

\author{
Andis Suci Aulia, Sukirno \\ Program Studi Magister Kenotariatan, \\ Fakultas Hukum, Universitas Diponegoro \\ Email : andissuciaulia1997@gmail.com
}

\begin{abstract}
This study discusses the causes of the people of Nanga Kalis Village that have not yet registered their land. Lack of community knowledge about land registration is the cause. This research was conducted in an approach method used is empirical juridical, and research specifications are analytical description, collection obtained from primary data that is data obtained directly from respondents through interviews with the Head of Nanga Kalis Village to obtain accurate data, and secondary data namely data obtained by studying literature, legislation. The factor that causes the community to not register their land is because they do not know the procedures and procedures for registering land.
\end{abstract}

Keywords: land registration; legal certainty; certainty of land rights.

\begin{abstract}
Abstrak
Studi ini membahas penyebab masyarakat Desa Nanga Kalis yang belum mendaftarkan tanah mereka. Kurangnya pengetahuan masyarakat tentang pendaftaran tanah adalah penyebabnya. Penelitian ini dilakukan dengan pendekatan yuridis empiris, dan spesifikasi penelitian adalah deskripsi analitis, pengumpulannya diperoleh dari data primer yaitu data yang diperoleh langsung dari responden melalui wawancara dengan Kepala Desa Nanga Kalis untuk mendapatkan data yang akurat, dan data sekunder yaitu data diperoleh dengan mempelajari literatur, hukum. Faktor yang menyebabkan masyarakat tidak mendaftarkan tanah mereka adalah karena mereka tidak tahu prosedur dan prosedur pendaftaran tanah.
\end{abstract}

\section{Kata kunci: pendaftaran tanah; kepastian hukum; kepastian hak atas tanah.}

\section{A. Pendahuluan}

Tanah adalah karunia Tuhan Yang Maha Esa merupakan sumber daya alam yang sangat diperlukan manusia untuk mencukupi kebutuhan, baik yang langsung untuk kehidupannya sepertinya untuk bercocok tanam atau tempattinggal, maupun untukmelaksanakan usaha, seperti untuk tempat perdagangan, industri, pertanian, 
perkebunan, pendidikan, pembangunan sarana dan prasana lainnya. Pemberdayaan sumber daya alam yang sangat terbatas harus dapat mengimbangi tingkat pertumbuhan kelahiran manusia yang sedemikian pesat karena seluruh sumber daya alam khususnya tanah bersifat unrenewable.(Syarief, 2012)

Tanah merupakan salah satu sumber daya alam yang sangat penting di dalam kehidupan manusia. Tanah merupakan bagian dari bumi, air dan ruang angkasa yang merupakan bagian dari kekayaan alam yang berlimpah sebagai karunia dari Tuhan Yang Maha Esa. Oleh karena itu sudah seharusnya kita melestarikan, menjaga dan mengelola secara baik tanah tersebut baik untuk generasi sekarang maupun untuk yang akan datang. Sebagai sumber daya yang sangat menunjang kehidupan umat manusia, maka setiap masyarakat memiliki aturan atau norma tertentu dalam penggunaan, penguasaan, pemilikan dan pemanfaatan tanah untuk kehidupannya. Dengan semakin berkembangnya penduduk dan cara pemikiran manusia maka mendorong terbentuknya suatu aturan di bidang pertanahan yang dapat diterima bersama sebagai landasan hukum terutama dalam kepemilikan tanah.

Fungsitanah di Negara Indonesia mempunyai fungsi yang sangat penting dalam rangka mewujudkan kesejahteraan masyarakat sebagaimana yang diamanatkan dalam UUD 1945. Agar bumi, air dan ruang angkasa dapat berfungsi dengan baik dan tepat, maka pemanfaatannya perlu diatur dengan undang-undang yang termasuk lingkup hukum agraria.(Chomzah, 2002) Dengan demikian bahwa undang-undang pertanahan di Indonesia sudah jelas sebagaimana yang diatur dalam PP No. 24 tahun 1997 tentang pendaftaran tanah. Namun pada hakekatnya masyarakat sampai saat ini masih belum menggunakan hak - hak atas kepemilikan tanah itu untuk didaftarkan dan diberikan tanda bukti kepemilikannya baik itu berupa Akta Jual Beli, Akta Hibah, Akta Waris sampai kepada sertifikat disebabkan adanya kendala-kendala teknis yang dirasaka nmasyarakat dalam mendaftarkan tanahnya baik itu berupa ekonomi maupun berupa teknis administrasi yang dilakukan oleh pihak pejabat pembuat akta tanah (PPAT).(Hardjono, 2003)

Dalam era pembangunan dewasa ini, arti dan fungsi tanah bagi negara Indonesia tidak hanya menyangkut kepentingan ekonomi semata, tetapi juga mencangkup aspek sosial dan politik serta aspek pertanahan keamanan. Kenyataanmenunjukkan bahwa semakin meningkatnya kebutuhanakan tanah untuk pembangunan, maka pola hidup dan 
kehidupan masyarakat baik di perkotaan maupun di pedesaan menjadi lain. Adanya perubahan sikap yang demikian dapat dimaklumi karena tanah bagi masyarakat Indonesia merupakan sumber kemakmuran dan juga kesejahteraan dalam kehidupan. Dengan demikian dapat dikatakan bahwa tanah bagi masyarakat Indonesia merupakan salah satu hal yang amat penting guna menjamin kelangsungan hidupnya. Menyadari akan fungsi tersebut maka pemerintah berusaha meningkatkan pengelolaan, pengaturan dan pengurusan di bidang pertanahan yang menjadi sumber kemakmuran dan kesejahteraan.(Soeradjo, 2003)

Kendala yang dihadapi adalah pertumbuhan penduduk terus meningkat, sedangkan ketersediaan tanah yang sangat terbatas. Karena terbatasnya tanah yang tersedia dan kebutuhan akan tanah semakin bertambah, dengan sendirinya akan menimbulkan benturan-benturan kepentingan akan tanah, yang berakibat akan menimbulkan permasalahan atas tanah. Karenanya oleh pemerintah kebijaksanaan mengenai tanah ini diatur dalam berbagai ketentuan-ketentuan peraturan perundang-undangan. Pada tahun 1960 Indonesia berhasil membentuk peraturan perundang- undangan mengenai pertanahan dalam bentuk undang-undang yang disebut undang-undang No. 5 Tahun 1960 tentang Peraturan Dasar Pokok- Pokok Agraria yang dikenal dengan UUPA yang mulai berlaku sejak tanggal 24 September 1960.

Dasar hukum pendaftaran tanah diatur Undang-Undang Pokok Agraria (UUPA) dalam ketentuanPasal 19 yang berbunyi:

"Untuk menjamin kepastian hukum oleh Pemerintah diadakan pendaftaran tanah di seluruh wilayah Republik Indonesia menurut ketentuan-ketentuan diatur dengan Peraturan Pemerintah. Pendaftaran tersebut dalam ayat 1 pasal ini meliputi: Pengukuran, perpetaan dan pembukuan tanah, pendaftaran hak-hak atas tanah dan peralihan hak-hak tersebut, pemberian surat-surat tanda bukti hak, yang berlaku sebagai alat pembuktian yang kuat."

Pendaftaran tanah dilaksanakan berdasarkan asas sederhana, aman, terjangkau, mutakhir dan terbuka yang tercantum di dalam Pasal 2 Peraturan Pemerintah Nomor 24 Tahun 1997, sedang dalam Pasal 3 Peraturan Pemerintah Nomor 24 Tahun 1997, menerangkan bahwa pendaftaran tanah bertujuan:

1. Untuk memberikan kepastian hukum dan perlindungan hukum kepada pemegang hak atas suatu bidang tanah, satuan rumah susun dan hak-hak lain 
yang terdaftar agar dengan mudah dapat membuktikan dirinya sebagai pemegang hak yang bersangkutan

2. Untuk menyediakan informasi kepada pihak-pihak yang berkepentingan termasuk Pemerintah agar dengan mudah dapat memperoleh data yang diperlukan dalam mengadakan perbuatan hukum mengenai bidang-bidang tanah dan satuan-satuan rumah susun yang sudah terdaftar

3. Untuk menyelenggarakan tertib administrasi pertanahan.(Anshari Siregar, 2007)

Dari fenomena-fenomena yang terjadi dalam kenyataannya masih banyak masyarakat di Indonesia yang belum sepenuhnya melaksanakan pendaftaran tanah. Khususnya masyarakat Desa Nanga Kalis Kecamatan Kalis Kabupaten Kapuas Hulu Kalimantan Barat masih sangat rendah. Pendaftaran tanah mempunyai tujuan positif dalam memberikan jaminan kepastian hukum mengenai hak atas tanah bagi semua orang tanpa membedakan status, yakni dengan memberikan surat tanda bukti yang lazim disebut dengan sertifikat tanah yang berlaku sebagai alat pembuktian yang kuat terhadap pemegang hak atas tanah. Tujuan pendaftaran tersebut akan tercapai dengan adanya peran serta dan dukungan pelaksanaan pendaftaran tanah tersebut baik oleh pemerintah selaku pejabat pelaksana pendaftaran tanah maupun kesadaran masyarakat selaku pemegang hak atas tanah.

Sehubungan dengan hal itu maka Pemerintah telah mengantisipasi dengan diundangkannya Undang-Undang Nomor 5 Tahun 1960 yang biasa disebut UUPA, agar menyelenggarakan pendaftaran tanah di seluruh wilayah Indonesia. Hal tersebut bertujuan untuk memberikan kepastian hukum hak atas tanah. Pendaftarantanah tersebut kemudian diatur lebih lanjut dengan Peraturan Pemerintah Nomor 24 Tahun 1997 tentang pendaftaran tanah.(Harsono, 2005)

Sejak berlakunya UUPA hingga sekarang pendaftaran tanah di Desa Nanga Kalis belum mencapai hasil seperti yang diharapkan, karena sebagian besar dari pemegang hak atas tanah belum secara teratur melaksanakan kewajibannya untuk mendaftarkan tanahnya pada Kantor Pertanahan Kabupaten Kapuas Hulu. Berdasarkan data yang diperoleh kecamatan Nanga Kalis mempunyai luas wilayah $\pm 1.519,58 \mathrm{~km}$ dengan jumlah penduduk sampai saat ini 536 Kepala Keluarga, dan hingga sekarang hanya sebagian kecil tanah yang sudah didaftarkan dan bersertifikat, itupun di dapat melalui Proyek Operasi 
Nasional Agraria (PRONA). Dalam rentang waktu semenjak diterbitkannya sertipikat melalui PRONA, tidak pernah ada lagi penyelenggaraan pendaftaran tanah di Desa Nanga Kalis.

Sertifikat merupakan hasil akhir dari kegiatan pendaftaran tanah. Sertifikat hak atas tanah sebagai hasil akhir proses pendaftaran tanah yang berisi data fisik (keterangan tentang letak, batas, bidang tanah, serta bangunan yang ada di atasnya) dan data yuridis (keterangan tentang status tanah dan bangunan yang didaftar, pemegang hak atas tanah dan hak-hak pihak lain serta beban-beban lain yang berada di atasnya) merupakan tanda bukti yang kuat. Dengan memiliki sertifikat, maka kepastian hukum berkenaan dengan jenis hak atas tanahnya, subjek hak dan objek haknya menjadi nyata selain hal tersebut sertifikat memberikan berbagai manfaat, misalnya mengurangi kemungkinan sengketa dengan pihak lain, serta memperkuat posisi tawar menawar apabila hak atas tanah yang telah bersertifikat diperlukan pihak lain untuk kepentingan pembangunan apabila dibandingkan dengan tanah yang belum bersertifikat serta mempersingkat proses peralihan serta pembebanan hak atas tanah.(Santoso, 2010)

Sertifikat merupakan surat tanda bukti hak yang terdiri dari salinan buku tanah dan surat ukur, diberi sampul, dijilid menjadi satu yang bentuknya ditetapkan oleh Menteri Negara Agraria/Kepala Badan Pertanahan Nasional (BPN).(SP Sangsun, 2007) Ada dua jenis sertifikat. Pertama, sertifikat yaitu tanda bukti hak yang diberikan bagi tanah-tanah yang sudah ada surat ukurnya ataupun tanah-tanah yang sudah diselenggarakan pengukuran desa demi desa, dan yang kedua, sertifikat sementara, yaitu tanda bukti hak yang diberikan bagi tanah- tanah yang belum ada surat ukurnya, artinya tanah-tanah di desa-desa yang belum dihitung berdasarkan pengukuran desa demi desa. Sertifikat merupakan alat pembuktian yang kuat, baik subyek maupun obyek hak atas tanahnya dan sertifikat sementara merupakan alat pembuktian sementara mengenai macam-macam hak dan siapa pemiliknya, tidak membuktikan mengenai luas dan batas-batas tanahnya.

Begitu pentingnya sertifikat tanah ini sehingga setiap pemilik tanah yang sah dianjurkan untuk segara mendaftarkan bidang tanahnya ke kantor pertanahan setempat. Namun demikian dalam kenyataannya tidak jarang masyarakat yang tidak peduli dengan pendaftaran tanahnya, hal ini diakibatkan karena tingkat ekonomi yang masih rendah, tingkat pendidikan yang masih rendah, ketidakpedulian BPN Kabupaten Kapuas Hulu dalam memberikan dukungan atau program-program kepada masyarakat Desa Nanga 
Kalis Kabupaten Kapuas Hulu agar mudah mengurus sertifikat tanah sehingga masyarakat khususnya masyarakat Desa Nanga Kalis lebih mementingkan kebutuhan pokok mereka daripada harus mendaftarkan tanahnya demi kepastian hukum tanahnya. Apalagi terdengar isu-isu dari masyarakat setempat yang pernah mendaftarkan tanahnya bahwa dalam mendaftarkan tanah itu prosesnya lama dan biayanya mahal. Kenyataan yang terjadi adalah pelayanan yang masih lambat, sulit, dan berbelit-belit. Hal ini membuat masyarakat menjadi enggan untuk mendaftarkan tanahnya, bagi masyarakat Desa Nanga Kalis yang terpenting ada saksi-saksi yang mengetahui batas-batas tanahnya dari tanah yang dimilikinya itu sudah cukup untuk menguatkan hak atas tanahnya tersebut.

\section{Kerangka Teori}

Banyak masyarakat yang belum mendaftarkan tanahnya dapat berdampak buruk dan membahayakan masyarakat itu sendiri, oleh sebab itu untuk untuk menjamin kepastian hukum harus ada penegasan dari semua pihak, melalui dari pihak Kantor Pertanahan Kabupaten Kapuas Hulu, pihak kantor Kecamatan Nanga Kalis, bahkan Kepalas Desa Nanga Kalis. Lalu aturan-aturan serta tata cara pendaftaran tanah hendaknya di sosialisasikan kepada masyarakat, melihat realita di masyarakat masih banyak yang belum mengerti sehingga mereka belum mendaftarkan tanahnya.

Dikemudian hari masyarakat yang belum mendaftarkan tanahnya akan merasakan dampak negatif karena tidak ada jaminan kepastian hukum atas tanah mereka. Di dalam UUPA Nomor 5 Tahun 1960, dalam Pasal 19 ayat (1) memerintahkan diselenggarakan pendaftaran tanah dalam rangka menjamin kepastian hukum. Kepastian hukum yang dijamin itu, meliputi kepastian mengenai:

1. letak, batas dan luas tanah;

2. status tanah dan orang yang berhak atas tanah;

3. pemberian surat berupa setipikat.

Selanjutnya di dalam ayat (2) menentukan bahwa pendaftaran tanah yang dimaksud dalam ayat (1) meliputi:

a. pengukuran, pemetaan, dan pembukuan tanah;

b. pendaftaran hak-hak atas tanah dan peralihan hak-hak tersebut;

c. pemberian surat-surat tanda bukti hak, yang berlaku sebagai alat pembuktian yang kuat.(Parlindungan, 1999) 
Adapun permasalahan dalam pemaparan latar belakang diatas adalah:

1. Faktor apa yang menyebabkan masyarakat Nanga Kalis belum mendaftarkan tanahnya?

2. Bagaimana kesadaran masyarakat Desa Nanga Kalis dalam pendaftaran tanah?

\section{Kebaruan/Orisinalitas Hasil Penelitian}

Penulis menelaah sumber informasi baik dari buku, undang-undang atau penelitian terdahulu yang dijadikan sumber informasi dan perbandingan dalam mendapatkan jawaban atas permasalahan-permasalahan tersebut.oleh karena itu, untuk mengetahui validasi penelitian yang penulis lakukan, maka dala telaah pustaka ini, penulis akan uraikan beberapa penelitian yang sudah ada dan relevan dengan pembahasan jurnal tersebut, antara lain:

Pertama jurnal yang ditulis Mira Novana Ardani yang berjudul "Tantangan Pelaksanaan Kegiatan Pendaftaran Tanah Sistematis dalam Rangka Mewujudkan Pemberian Kepastian Hukum”(Novana Ardani, 2019) kemudian kedua jurnal yang ditulis Ana Silviana yang berjudul "Kajian Tentang Kesadaran Hukum Masyarakat dalam Melaksanakan Pendaftaran Tanah"(Silviana, 2012) dan jurnal yang ditulis Anugerah Novantri Zebua yang berjudul "Kesadaran Hukum Masyarakat Nias Dalam Rangka Pendaftaran Tanah Di Kabupaten Nias (Studi Kasus Di Kabupaten Nias)(Novantri Zebua, 2015)" meskipun dari jurnal penulis dan jurnal-jurnal terdahulu sama-sama membahas tentang pelaksanaan tanah tetapi hanya menjadikan semua acuan dalam penulisan jurnal yang akan dibuat penulis yang berkenaan dengan pendaftaran tanah dengan mengangkat judul Pelaksanaan Pendaftaran Tanah Oleh Pemegang Haknya Di Desa Nanga Kalis Kecamatan Kalis Kabupaten Kapuas Hulu Kalimantan Barat.

\section{B. Metode Penelitian}

Metode pendekatan yang digunakan yaitu pendekatan sosio legal.(Shidarta, 2009) Socio legal merupakan penelitian yang mengkaji penerapan kaidah-kaidah atau normanorma hukum dengan menggunakan pendekatan ilmu hukum maupun ilmu-ilmu social. Metode penelitian sosio legal merupakan kombinasi antara metode penelitian hukum doktriner dan metode penelitian hukum empirik, maka yang dilakukan oleh peneliti adalah studi dokumen yang disertai dengan studi lapangan. Studi dokumen dalam penelitian ini adalah kepustakaan dengan menggunakan peraturan perundang-undangan. 
Spesifikasi dalam penelitian ini adalah deskriptif analitis, yaitu penelitian yang dilakukan dengan cara menggambarkan keadaan di desa Nanga Kalis sebagaimana adanya yang terjadi berdasarkan data yang terkumpul secara jelas dan menyeluruh sehingga akan dianalisis guna memperoleh kebenaran pada kesimpulan akhir.

Teknik pengumpulan data yang digunakan adalah data primer sebagai data utama yang diperoleh dari lapangan, data primer adalah data yang diperoleh dari teknik wawancara langsung kepada subyek yang ada hubungannya dengan permasalahan dalam penelitian ini. Data primer ini diperoleh dengan cara wawancara secara langsung dengan responden dan pengamatan terhadap obyek yang diteliti. Data dalam penelitian hukum merupakan data penunjang yang menjadi bekal dalam melakukan penelitian lapangan.Alat pengumpulan data dalam penelitian ini adalah penelitian kepustakaan, penelitian dilakukan degan mempelajari literatur-literatur, undang-undang dan peraturanperaturan lain, serta pendapat para sarjana yang berhubungan erat dengan masalah penelitian. Wawancara secara langsung dengan masyarakat Desa Nanga Kalis untuk memperoleh keterangan langsung tentang masih banyak masyarakat Desa Nanga Kalis yang belum mendaftarkan tanahnya. Wawancara dilakukan dengan cara tanya jawab secara langsung dimana semua pertanyaan disusun secara sistematis.(Nasution, 2008)

\section{Hasil Dan Pembahasan}

\section{Faktor Penyebab Masyarakat Desa Nanga Kalis Belum Mendaftarkan Tanahnya}

Tanah sangatlah penting bagi kehidupan manusia, sebab tanah merupakan salah satu sumber kehidupan yang sangat vital bagi manusia, baik fungsinya sebagai sarana mencari kehidupan (mata pencaharian), maupun sebagai tempat bermukim. Seiring dengan berkembangnya jumlah penduduk, kebutuhan akan tanah kadang-kadang menimbulkan perselisihan kepentingan sehingga masalah pertanahan menjadi hal yang sering dihadapi masyarakat. Dengan meningkatnya kebutuhan akan tanah, maka dibutuhkan pula suatu jaminan kepastian hukum di bidang pertanahan.

Untuk memenuhi jaminan kepastian hukum di bidang pertanahan, dibutuhkan suatu perangkat hukum yang jelas dan tertulis yang pelaksanaannya sesuai dengan ketentuan yang berlaku. Dalam menjamin kepastian hukum sehubungan dengan kepemilikan dan penguasaan tanah melingkupi kepastian mengenai subjek dan objek dari hak atas tanah, maka setiap bidang tanah harus didaftarkan untuk memperoleh Sertipikat sebagai tanda bukti hak yang kuat dan demi terciptanya tertib pertanahan. Seperti yang telah dipaparkan 
dalam latar belakang ternyata masih banyak bidang tanah masyarakat Desa Nanga Kalis yang belum didaftarkan, dan hal ini tidak boleh diabaikan.

Pendaftaran tanah merupakan hal yang sangat penting dan perlu mendapat perhatian secara serius dan seksama dalam rangka pengumpulan data dan menentukan status atau pemilikan dan penguasaan atas sebidang tanah.Pada masyarakat Desa Nanga Kalis kegiatan pendaftaran tanah sangat jarang dilakukan. Kurangnya pemahaman tentang pendaftaran tanah membuat masyarakat selama ini hanya menggunakan SKT sebagai tanda bukti untuk hak atas tanah mereka.

Faktor dan kendala masyarakat Desa Nanga Kalis belum mendaftarkan tanahnya sebagian besar dikarenakan oleh ketidaktahuan masyarakat Desa Nanga Kalis tentang tata cara dan prosedur pendaftaran tanah. Mengetahui dan mengerti dalam pelaksanaan pendaftaran tanahdapat meningkatkan minat masyarakat dalam melakukan pendaftaran tanah. Informasi-informasi yang akan di peroleh langsung masyarakat dari Kantor Pertanahan tentang pendaftaran tanah dapat menjadi pengetahuan bagi masyarakat yang akan melakukan pendaftaran tanah. Pengetahuan tentang pentingnya pendaftaran tanah juga dapat menambah kesadaran hukum masyarakat Desa Nanga Kalis. Adanya kegiatan pendaftaran tanah itu sendiri diharapkan dapat membuat masyarakat Desa Nanga Kalis dan seluruh rakyat Indonesia terhindar dari suatu permasalahan tanah dan sengketa yang melibatkan suatu bidang tanah yang belum didaftarkan.

Masyarakat yang sudah memegang SKT berpendapat bahwa sudah cukup bagi mereka untuk menguasai tanah tersebut dan hanya memegang SKT. Pemahaman mereka adalah bahwa SKT tersebutlah yang dianggap sebagai surat tanah (sertifikat). SKT tersebutlah yang dianggap mereka sebagai bukti tertulis terkuat jika terjadi suatu gugatan (sengketa tanah). Berdasarkan hasil yang diperoleh dari penelitian, menunjukkan pemahaman masyarakat akan pendaftaran tanah sangat minim. Bahkan sebagian besar dari pemilik tanah tersebut tidak mengerti dan belum pernah mendengarkan istilah pendaftaran tanah maupun sertipikat tanah. Keadaan ini juga menunjukkan minimnya pemahaman masyarakat akan manfaat dan tujuan pendaftaran tanah itu. Dari keterangan masyarakat juga diketahui bahwa beberapa masyarakat belum pernah mengikuti suatu sosialisasi maupun penyuluhan hukum mengenai pendaftaran tanah. Jadi masyarakat pemilik tanah tidak mengetahui bahwa suatu bidang tanah harus didaftarkan ke Kantor 
Pertanahan dan memperoleh sertipikat, sehingga akan menjamin kepastian hukum bagi bidang tanah yang dikuasainya.

Berbeda dengan masyarakat kota yang setiap saat dapat mengakses internet untuk mencari informasi hukum, maka di pedesaan, jika pemerintah tidak mensosialisasikannya langsung kepada masyarakat, maka masyarakat akan memiliki pengetahuan hukum yang minim. Begitu juga keadaan masyarakat di Desa Nanga Kalis yang jarang sekali mendapatkan sosialisasi hukum mengenai pendaftaran tanah oleh Kantor Pertanahan Kabupaten Kapuas Hulu. Jadi, minimnya pengetahuan hukum masyarakat menjadi salah satu faktor masyarakat di Desa Nanga Kalis Kecamatan Kalis Kabupaten Kapuas Hulu belum mendaftarkan tanahnya.

\section{Kesadaran Hukum Masyarakat Desa Nanga Kalis}

Kesadaran hukum pada dasarnya terletak pada hati nurani manusia itu sendiri. Akan tetapi semakin hari, kesadaran hukum tersebut semakin merosot. Oleh sebab itu, salah satu cara menumbuhkannya kembali adalah dengan memberi penerangan atau sosialisasi hukum dan peraturan perundang-undangan kepada masyarakat. Masyarakat Desa Nanga Kalis memiliki pemahaman yang kurang akan arti penting pendaftaran tanah, sementara sosialisasi peraturan perundang-undangan yang mengatur hal tersebutpun tidak pernah disosialisasikan kepada mereka.

Perlu perhatian lebih dari pemerintah ataupun pejabat setempat untuk sosialisasi hukum tentang tata cara atau prosedur pendaftaran tanah yang benar agar setiap masyarakat mengerti tentang tata cara dan prosedur pendafatran tanah tersebut. kurangnya pemahaman masyarakat akan arti penting pendaftaran tanah. Masyarakat mengakui bahwa mereka tidak mengerti dan mengetahui bahwa bidang-bidang tanah yang dikuasainya harus didaftarkan.

Kepala Desa Nanga Kalis mengatakan faktor lain yang mayarakat keluhkan yaitu banyaknya masyarakat yang menganggap bahwa pendaftaran tanah sangat mahal dan membutuhkan proses yang lama menjadi alasan untuk tidak melakukan pendaftaran tanah. Masyarakat Desa Nanga Kalis merasa takut jika mereka mendaftarkan tanah, mungkin Pajak Bumi dan Bangunan atau pajak-pajak lainnya akan semakin mahal maka dari itu masyarakat bagi masyarakat Desa Nanga Kalis mendaftarkan tanah bukan merupakan kebutuhan pokok. Masyarakat meminta agar dilakukannya lagi kegiatan pendaftaran tanah secara sistematis (massal) karena biaya yang dikeluarkan jauh lebih 
ringan dan masyarakat akan dibantu oleh aparat desa untuk melengkapi berkas yang dibutuhkan.

Pada dasarnya, karena pendaftaran tanah itu adalah semata-mata untuk memperoleh jaminan kepastian hukum dan hak, maka data-data yang diperoleh haruslah sesuai dengan keadaan yang sebenarnya dari pada status tanah tersebut. Karena itu diperlukan suatu ketelitian yang cermat dalam memperoleh data baik dalam penyelenggaraan pendaftaran tanah maupun kegiatan mengenai pemeliharaannya.

Dalam Peraturan Pemerintah No. 24 Tahun 1997, kegiatan pendaftaran tanah dikenal dengan istilah "ajudikasi" yang artinya adalah kegiatan yang dilakukan/dilaksanakan dalam proses pendaftaran tanah pertama kali yang meliputi pengumpulan kebenaran data fisik dan data yuridis mengenai 1 (satu)/beberapa objek pendaftaran tanah untuk keperluan pendaftarannya. Jadi, menurut Peraturan Pemerintah No. 24 Tahun 1997, rangkaian kegiatan pendaftaran tanah adalah sebagai berikut:

1. Kegiatan Fisik

Pendaftaran/pembuktian yang pertama kalo, disebut "Initial Registration" sehingga tanah yang semula belum didaftar menjadi terdaftar.

Dalam Peraturan Pemerintah No. 10 Tahun 1961 yang disempurnakan dengan Peraturan Pemerintah No. 24 Tahun 1997, “Initial Registration” diselenggarakan dengan 2 (dua) cara yaitu:

a. pendaftaran dilakukan desa demi desa, dalam arti semua tanah yang ada di desa dikumpulkan datanya, cara ini disebut "Sistematic Intial Registration".

b. dalam Peraturan Pemerintah No. 10 Tahun 1961 mapun Peraturan Pemerintah No. 24 Tahun 1997 mengharuskan tanah yang di desa lainnya juga didaftarkan, tetapi pendaftarannya dilakukan secara "individual/sporadik", secara perseorangan. Cara ini dinamakan "individual/sporadik registration".

Kegiatan-fisik dalam "sistematik initial registration" dimulai dari:

a. menetapkan lokasi di mana letak tanah

b. menetapkan batas-batasnya

Mengenai bagaimana cara menetapkan batasnya, menurut teori di berbagai negara dilakukan dengan berbagai cara menurut Peraturan Pemerintah No. 24 Tahun 1997, cara yang digunakan adalah dengan mempersilahkan pemilik tanah menunjuk sendiri batasbatasnya dan kemudian meminta persetujuan dari merka yang punya tanah berbatasan. 
Jadi menurut peraturan batas itu di tetapkan bersama. Bila ada perselisihan bari diajukan ke Pengadilan, keputusan Pengadilan dengan cara ini dinamakan "delimitasi kontra diktur".

c. kemudian diberi tanda batas di setiap tanah yang ditetapkan, bisa berupa besi atau beton

d. dilakukan pengukuran

e. diadakan pemetaan

2. Kegiatan Yuridis

Kepastian yang dicari dalam kegiatan ini adalah "tanah tersebut haknya apa dan siapa pemegang haknya?"Cara menetapkan status tanah tersebut, yaitu:

a. mengumpulkan dana/surat/dokumen mengenai tanah tersebut yang akan memperlihatkan status tanah, kemudian ditentukan siapa pemegang haknya, setelah itu dilihat pula apakah ada hak.hak lain di atasnya.

b. bila data-data itu sudah lengkap lalu dituangkan dalam isian dan diumumkan di Kantor Kelurahan/Kecamatan untuk memberitahukan kepada masyarakat agar bisa mengajukan keberatan. Apabila tidak ada yang mengajukan keberatan, data tesebut disahkan.

\section{Kegiatan Penerbitan Sertipikat}

Penerbitan tanda bukti hak yaitu Sertipikat Hak Atas Tanah, isinya dalam "sistematic initial registration" adalah surat ukur yang merupakan kutipan dari peta pendaftaran tanah dan salinan buku tanah. Sertipikat ini isinya tergantung dari letak tanah di desa, dalam sistem "sistematic initial registration" letak tanah umumnya di sesan lengkap, sertipikatnya berisi surat ukur dan salinan buku tanah yang ada pada satu sampul. Sedangkan desa yang belum lengkap/desa yang belum punya peta pendaftaran yang ada hanya peta dasar.

4. Kegiatan Pemeliharaan Data Fisik dan Data Yuridis

Menurut Peraturan Pemerintah No. 24 Tahun 1997, kegiatan pendaftaran tanah di tambah satu yaitu pemeliharaan data fisik dan data yuridis. Menurut Pasal (36) ayat 1 Peraturan Paemerintah No. 24 Tahun 1997 pemeliharaan data pendaftaran tanah dilakukan apabila terjadi perubahan pada data fisik atau data yuridis objek pendaftaran tanah yang telah terdaftar. 


\section{Simpulan}

Berdasarkan uraian di atas, maka dapat disimpulkan bahwa masih banyak masyarakat Desa Nanga Kalis Kecamatan Kalis Kabupaten Kapuas Hulu yang belum mendaftarkan tanahnya, sehingga masyarakat Desa Nanga Kalis belum memperoleh jaminan kepastian hukum dan perlindungan hukum di bidang pertanahan. Faktor penyebab mayarakat Desa Nanga Kalis belum mendaftarkan tanahnya adalah dikarenakan tidak mengetahui prosedur dan tata cara pendaftaran tanah, biaya yang mahal, dan juga karena masyarakat Desa Nanga Kalis sudah mempunyai SKT sebagai tanda kepemilikan tanah mereka.

\section{DAFTAR PUSTAKA}

\section{BUKU}

Anshari Siregar, T. (2007). Pendaftaran Tanah Kepastian Hak. Medan: Multi Grafik.

Chomzah, A. A. C. (2002). Hukum Agraria (Pertanahan Indonesia). Jakarta: Prestasi Pustaka.

Hardjono, I. (2003). Keterlibatan Hukum Dalam Masyarakat. Jurnal Ilmu Hukum, Vol 6 Nomo.

Harsono, B. (2005). Hukum Agraria Indonesia, Sejarah Pembentukan Undang-Undang Pokok Agraria, Isi dan Pelaksanaannya. Jakarta: Djambatan.

Nasution, S. (2008). Berbagai Pendekatan Dalam Proses Belajar dan Mengajar. Jakarta: Nasution, S.

Parlindungan, A. P. (1999). Pendaftaran Tanah di Indonesia. Bandung: CV. Mandar Maju.

Santoso, U. (2010). Pendaftaran Tanah dan Peralihan Hak Atas Tanah. Jakarta: Kencana.

Shidarta, S. I. dan. (2009). Metode Penelitin Hukum-konstelasi dan Refleksi. Jakarta. Soeradjo, I. (2003). Kepastian Hukum Atas Tanah Di Indonesia. Surabaya: Alkola. SP Sangsun, F. (2007). Tata Cara Mengurus Sertifikat Tanah. Jakarta: Visimedia. Syarief, E. (2012). Menuntaskan Sengketa Tanah Melalui Pengadilan Khusus Pertanahan. Jakarta: Kepustakaan Populer Gramedia. 


\section{JURNAL}

M. N. Ardani, "KEPEMILIKAN HAK ATAS TANAH BAGI ORANG ASING DI INDONESIA," LAW REFORM, vol. 13, no. 2, pp. 204-216, Sep.

2017. https://doi.org/10.14710//r.v13i2.16156

A. N. Zebua, Kesadaran Hukum Masyarakat Nias Dalam Rangka Pendaftaran Tanah Di Kabupaten Nias (Studi Kasus Di Kabupaten Nias), http://repository.usu.ac.id/handle/123456789/50273

Silviana, A. Kajian Tentang Kesadaran Hukum Masyarakat dalam Melaksanakan Pendaftaran Tanah. https://doi.org/10.15294/pandecta.v7i1.2371

\section{PERUNDANG-UNDANGAN}

Peraturan Menteri Agraria Nomor 3 Tahun 1997, tentang Pedoman-Pedoman Pokok Penyelenggaraan Pendaftaran Tanah.

Peraturan Pemerintah Nomor 10 Tahun 1961, tentang Pendaftaran Tanah.

Peraturan Pemerintah Nomor 24 Tahun 1997, tentang Pendaftaran Tanah.

Peraturan Presiden Nomor 10 Tahun 2006, tentang Badan Pertanahan Nasional.

Undang-Undang Nomor 5 Tahun 1960, tentang Peraturan Dasar Pokok-Pokok Agraria. 